\title{
Subsurface drip irrigation with reclaimed water: issues we must think now
}

\author{
M. M. H. Oliver, G. A. Hewa \& D. Pezzaniti \\ SA Water Centre for Water Management and Reuse (CWMR), \\ School of Natural and Built Environments, \\ University of South Australia, Australia
}

\begin{abstract}
Subsurface drip irrigation (SDI) is regarded as the most efficient and safe technology in reclaimed water irrigation schemes as it minimizes potential human exposure to low quality water. However, the system performance is often limited due to emitter clogging by complex biophysical activities as the whole assembly is laid underground. Growing evidence suggest that soil temperature is strongly correlated with emitter clogging although the dynamics of how it affects emitter performance is yet to be understood. This study analyses the thermal variation in rhizosphere including the consequent changes in recycled water quality and their implications on bio-fouling of emitters. In the northern horticultural district of Adelaide, seasonal variation of $18^{\circ} \mathrm{C}$ at $20 \mathrm{~cm}$ below the ground is very common and the recorded variation in any 10 year period is notably high $\left(25.8^{\circ} \mathrm{C}\right)$. Furthermore, the average diurnal variation is also important for operational purpose as the minimum and maximum soil temperature in any day would always occur in specific times. This variation in subsurface temperature affects reclaimed water quality primarily by regulating microbial growth in the labyrinth flow path of emitters. The ever changing level of microbial quality of recycled water still poses threat to sustainable practice of drip technology. The study concludes that future research, design and operation of reclaimed water irrigation schemes must account for these sustainability issues.
\end{abstract}

Keywords: subsurface drip irrigation, reclaimed water, rhizosphere, emitter clogging, biofilm. 


\section{Introduction}

Subsurface drip irrigation (SDI) is regarded as the most efficient form of micro irrigation because of its ability to minimize evaporation and runoff by wetting relatively small area of rhizosphere. In the recycled water irrigation schemes it also lowers the risk of physical contact of low quality water with the irrigators and crops, particularly for those crops with edible parts (fruit or leaf) growing above the soil. However, SDI systems supplying treated water often encounter poor performance due to emitter clogging [1-3]. If one emitter is clogged, partially or fully, it affects the whole system performance by decreasing the discharge of the clogged ones [4] and increasing the discharge of unclogged emitters [5] unless they are pressure compensated (PC). Therefore, minimizing emitter clogging is a challenge ahead for recycled water irrigation schemes.

\subsection{Background}

Three distinctive mechanisms of clogging have been identified in subsurface drippers supplying treated wastewater. They are physical, chemical and biological clogging attributed to the water quality issues [4, 6-8]. However, clogging is not caused purely by one of these three mechanisms; it is rather a combination of at least two that cause clogging [9]. Physical clogging has mainly been attributed to the suspended particles such as sand, silt and clay which are of inorganic origin. Traces of organic materials and microbial debris also cause physical clogging. On the other hand, chemical clogging occurs due to the interaction of dissolved solids in wastewater which precipitates to plug the flow of water $[2,10,11]$. The process of biological clogging is rather complex due to the diverse nature of recycled water as its quality changes with time and temperature. Formation of biofilms in the emitter flow path is the first stage of biological clogging [7]. Biofilms are a form of slimy gelatinous deposits secreted by micro-organisms predominantly from bacteria [12]. Algal contribution to clogging in SDI is generally small as the system operates under dark condition unless the storage facility is exposed to sunlight.

Though modern treatment plants and design approaches have optimized the water quality [13] and channel structure of emitters [14, 15] it could not eliminate clogging. This is because of the vibrant environment in the subsurface soil. Growing evidences from the United States [6, 16], Italy [1, 17], Spain [18] and many other parts of the world suggest that the thermal condition of soil and water can affect clogging. Despite many research efforts, very little is known of the relationship between clogging and the thermal changes that take place in the subsurface soil. The scope of this study encompasses these environmental and water quality factors that still posture threat to the sustainable practice of drip irrigation technology. While this paper specifically deals with the South Australian studies, most of the principles considered may well be conformed to scenarios in other countries and industries. 


\section{Study area and data}

The Mid Northern agricultural areas of the Northern and Yorke Agricultural District (NYAD) were selected for this study. NYAD includes the Yorke Peninsula, the Lower, Mid and Upper North areas of South Australia and parts of Adelaide Plains and Barossa Valley. Drip irrigation shares a considerable account of recycled water usage in this region including the city of Adelaide and clogging is very common in the reclaimed water irrigation schemes. While Barossa Valley is famous for its vineyards, Adelaide Plains is considered as a high value horticultural region in South Australia.

Three hourly soil temperature data at a depth of 20 at the Roseworthy Agricultural Weather Station from 2000 to 2011 was also collected for this study. This station is representative of the surrounding agricultural areas including parts of the hills. The data acquisition site has green vegetation cover reflecting actual field condition emitters face.

Recycled water samples were collected for analysis from the Bolivar DAFF wastewater treatment plant in South Australia which supplies recycled water to the Northern horticultural region of Adelaide Plains via Virginia pipeline scheme (Fig. 1). Data of recycled water quality supplied by the SA Water Corporation in the last 5 years were also collected for analyses [19]. The recycled water samples were analyzed for parameters including Chloride, $\mathrm{CaCO} 3$, Magnesium, Phosphorus, Potassium, Sodium and Nitrogen level using standard procedures in the laboratory of the Center for Water Management and Reuse (CWMR). These parameters also include suggestions by Capra and Scicolone [2] who proposed the most recent and accepted standard for predicting hazard rating of subsurface emitters

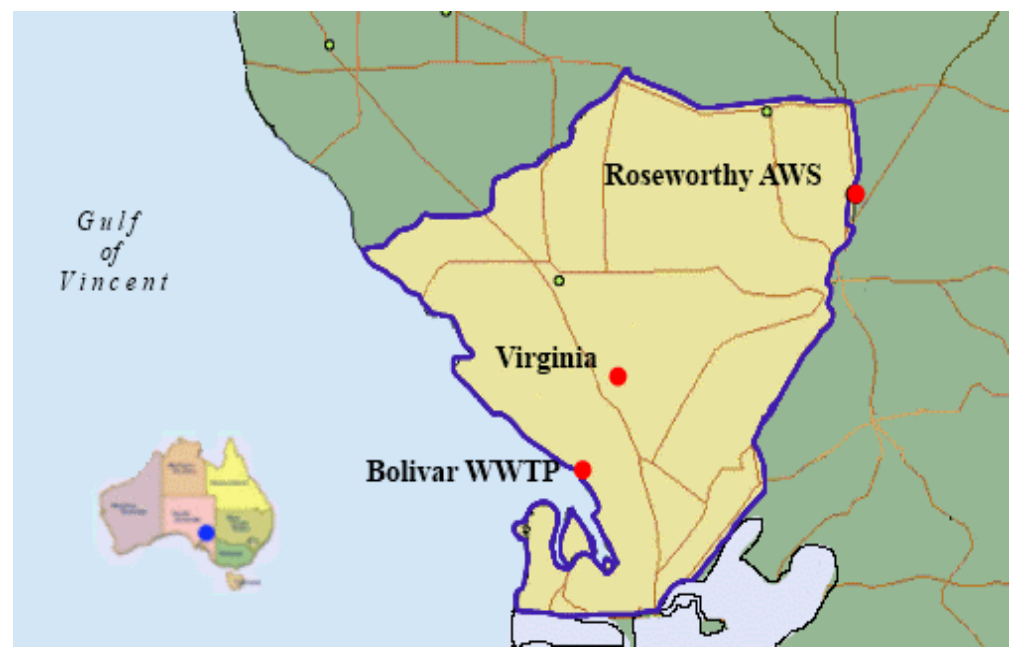

Figure 1: $\quad$ Study area at the mid northern Adelaide plains of South Australia. 


\section{Results and discussion}

\subsection{Soil thermal variation}

At $20 \mathrm{~cm}$ depth below the ground, the average thermal condition shows prominent seasonal variation of $18^{\circ} \mathrm{C}$. The ten year maximum $\left(34.4^{\circ} \mathrm{C}\right)$ and minimum $\left(8.6^{\circ} \mathrm{C}\right)$ shows even higher $\left(25.8^{\circ} \mathrm{C}\right)$ variation in the soil temperature regimes. It appears that diurnal variation in agricultural region is as low as $1.2^{\circ} \mathrm{C}$ during colder months despite higher changes above the ground. On the other hand, subsurface soil often experiences a diurnal change of $5^{\circ} \mathrm{C}$ or more during summer. This information is very important for operational purposes because the highest daily temperature in any day would arise between 6 and 9 o'clock in the evening while the lowest between 6 and 9 o'clock in the morning. Figure 1 shows the diurnal pattern and monthly temperature variation over 2000 to 2011 in the Adelaide plains horticultural region. It clearly depicts the clustered occurrence of seasonal soil temperatures in a year.

It is observed from Figure 1(a) that subsurface soil in NYAD experience similar $\left( \pm 1.2^{\circ} \mathrm{C}\right)$ thermal conditions during November, December and March while in June, July and August, values are clustered together $\left( \pm 0.5^{\circ} \mathrm{C}\right)$. Bimonthly clusters occur in the month of May/September $( \pm 0.05)$, April/October $( \pm 0.6)$ and January/February $( \pm 0.5)$. This information is crucial for sustainable practice SDI schemes in terms of irrigation scheduling and management of recycled water in irrigation. If the critical temperature range for clogging due to biophysical deposit is identified, SDI assembly can be operated accordingly for obtaining maximum performance. Based on this information, the recycled water quality can also be predicted and maintained for avoiding microbial growth in the labyrinth flow path of emitters. This will help prevent, if not, at least delay the initiation of bio-fouling in emitters in case of longer use.

\subsection{Water quality}

As noted in Section 2, reclaimed water for the study area is supplied from the Bolivar wastewater treatment plant (WWTP) that receives wastewater predominantly from sewage lines. Major water quality indicators obtained from the laboratory analysis of the reclaimed water samples are given in Table 1. Many of these elements still don't have any known hazard rating. For example, $\mathrm{CaCO}_{3}$ precipitation has been a major agent in chemical clogging [20] especially if $\mathrm{pH}$ is more than 7.5 , but its rating is still unknown. The dissolved solid level $(1048 \mathrm{mg} / \mathrm{l})$ found in sampled water shows the potential to clog emitters if biological quality deteriorates. Among other nutrients, the concentration of phosphorus in the sample was high enough $(1.7 \mathrm{mg} / \mathrm{l})$ to cause algal growth as the restricted level of has been set to $0.05 \mathrm{mg}$ of P/1 [21]. Presence of higher nitrogenous compounds in the reclaimed water has also been a major participant in biological clogging. Ayres and Wescot [22] reported correlation between microbial activity and nitrogen level in reclaimed water. The sample nitrogen level $(9.84 \mathrm{mg} / \mathrm{l})$ was notably higher than the optimum range $(0.1-1.6 \mathrm{mg} / \mathrm{l})$ for 
microbial growth. According to the available hazard ratings by Capra and Scicolone [2] and Bucks et al. [23], this water quality possesses moderate clogging risk for SDI emitters.

Table 1: Major water quality parameters of reclaimed water samples analysed in the laboratory.

\begin{tabular}{|c|c|c|c|}
\hline Water quality indicators & $\begin{array}{c}\text { Concentration } \\
(\mathbf{m g} / \mathbf{l})\end{array}$ & Water quality indicators & $\begin{array}{c}\text { Concentration } \\
(\mathbf{m g} / \mathbf{l})\end{array}$ \\
\hline $\mathrm{CaCO}_{3}$ & 121.50 & Calcium & 37.20 \\
\hline Bicarbonate & 152.40 & Potassium & 37.20 \\
\hline Sodium & 281.10 & Magnesium & 33.00 \\
\hline Chloride & 413.60 & Nitrate + Nitrite as N & 9.84 \\
\hline Manganese & 0.0130 & Phosphorus - Total & 1.70 \\
\hline
\end{tabular}

Modern recycled water treatment plants in recent years have improved the level of water treatments at lower costs. This has enabled many countries in the world to adopt their own standard of water quality. Reclaimed water is generally branded into four classes: A, B, C and D in Australia. The quality criteria for these classes and restriction on use vary from state to state. For instance, water of Class A in Victoria, is equivalent to Class A+ of Queensland [24]. Such

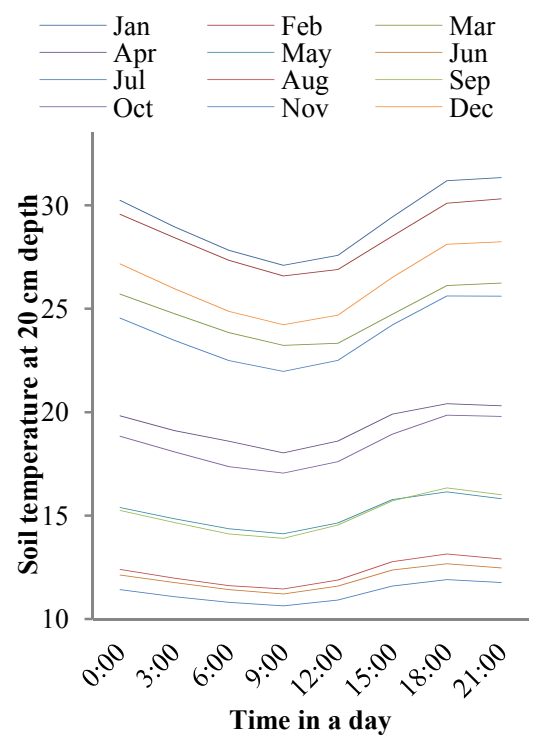

(a)

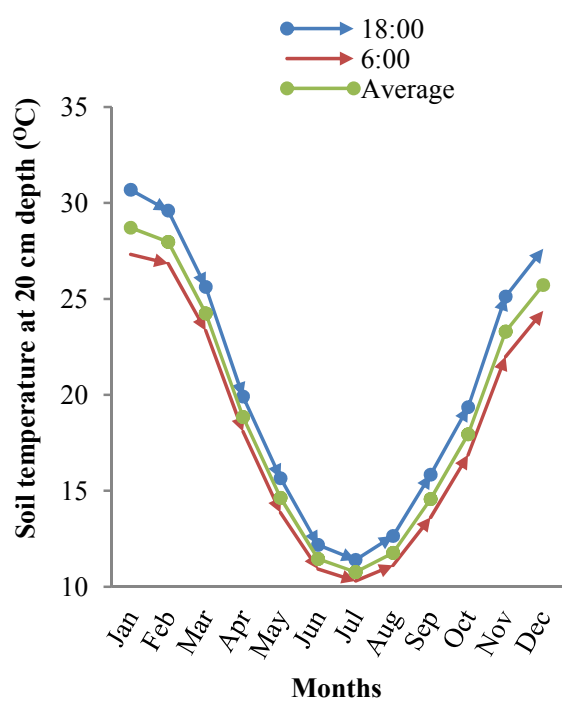

(b)

Figure 2: (a) 3 hourly diurnal soil temperature variation; (b) seasonal soil temperature variation. 
difference in water quality issues among the states of Australia has been reported in recent years $[25,26]$. Seasonal variations of water quality parameters at the Bolivar WWTP are shown in Figure 2. The plotted values are monthly averages estimated using historical observations from 2006 to 2011.

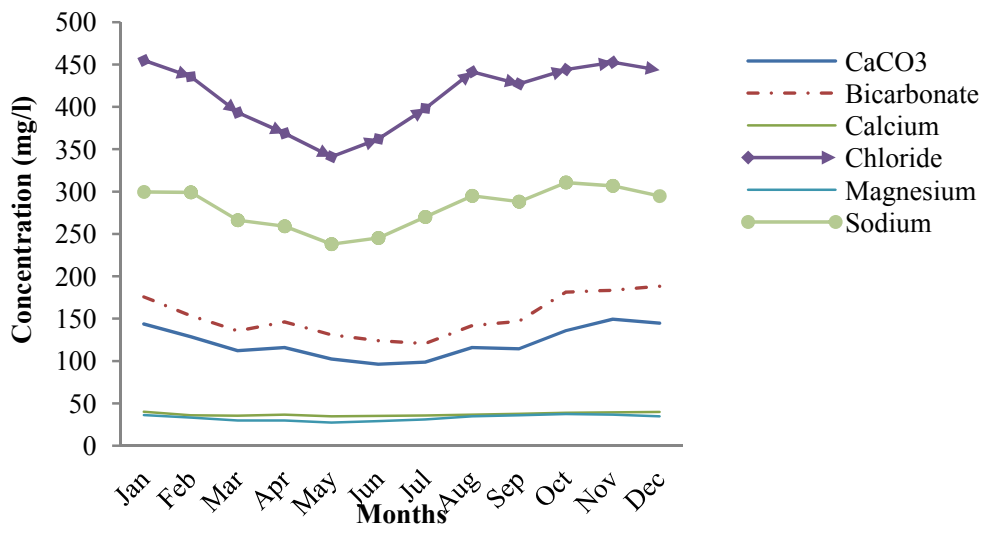

Figure 3: Monthly variation of major water quality parameters in Bolivar WWTP during 2006-2011.

The quality of reclaimed water analysed in this study is one of the highest in the world and falls into Class A category in South Australia. As can be observed from Figure 2, Sodium and bicarbonate level has been consistently high in the reclaimed water over the 5 year period. The other micronutrients are also present in moderate level. The bicarbonate $\left(\mathrm{HCO}_{3}{ }^{-}\right)$ion is one of the major contributors to alkalinity in irrigation water. In presence of high bicarbonate ion, calcium $(\mathrm{Ca})$ and magnesium $(\mathrm{Mg})$ can from insoluble precipitates and clog emitters. This reclaimed water like many other treated water in the world has a low level $(<1 \mathrm{mg} / \mathrm{l})$ of suspended solid (SS), contrasted by high level of dissolved solids $(>1100 \mathrm{mg} / \mathrm{l})$. If used in SDI schemes for long time, this quality water can jeopardise the sustainable agricultural practice.

Microbial quality of reclaimed water is also compromised because of the nature of operational practice in SDI. Residual chlorine level (usually $1 \mathrm{ppm}$ ) targeted by most treatment plants to disinfect outgoing reclaimed water has been proven to be ineffective against SDI clogging. The usual farming practice is to collect the water in bulk size, store it in the on farm reservoir (OFR) and use when necessary. Because of this delay between production and use of reclaimed water, chlorine level diminishes and disinfection bi-products appear, especially in waters with high nutrient level. Cyanobacterial bloom in recycled water OFRs is perhaps the most common example of this process in many parts of the world. Production of these toxins is often fostered by the ambient thermal condition $\left(15-30^{\circ} \mathrm{C}\right)$ of the rhizosphere, especially during the time of non-operative hours. This is inevitably followed by microbial adhesion, growth and development in the emitter flow path. The consequent slimy gelatinous substance ultimately 
blocks the flow from SDI emitters resulting in poor performance of the system. This draws in the necessity for better water quality management in SDI practice to make it sustainable

\section{Conclusion}

Although the reclaimed water quality of modern treatment plants is better than ever before, it still has the potential to clog drip emitters. Historical data and analysis of sampled water from Bolivar WWTP also supports this notion. Despite high class rating, this water quality still poses moderated clogging risk to emitters. Global experience also suggests similar SDI problems associated with reclaimed water quality. It is being explained in the study that understanding thermal variation in the subsurface soil can be used as a tool to help prevent clogging. This should be supported by better water quality management concentrating on the particular SDI issues. This study suggests that future design, operation and development of decision support systems must account for these issues for sustainable SDI practice.

\section{References}

[1] Capra, A. and Scicolone, B., Recycling of poor quality urban wastewater by drip irrigation systems. Journal of Cleaner Production, 15 (16), pp. 152934, 2007.

[2] Capra, A. and Scicolone, B., Water quality and distribution uniformity in drip/trickle irrigation systems. Journal of Agricultural Engineering Research, 70(4), pp. 355-65, 1998.

[3] Taylor, K. S., Anda, M., Sturman, J., Mathew, K., and Ho, G., Subsurface dripline tubing - an experimental design for assessing the effectiveness of using dripline to apply treated wastewater for turf irrigation in Western Australia. Desalination, 187(1-3), pp. 375-85, 2006.

[4] Ravina, I., Paz, E., Sofer, Z., Marcu, A., Shisha, A. and Sagi, G., Control of emitter clogging in drip irrigation with reclaimed wastewater. Irrigation Science, 13(3), pp. 129-39, 1992.

[5] Barragan, J., Bralts, V. and Wu, I. P., Assessment of Emission Uniformity for Micro-irrigation Design. Biosystems Engineering, 93 (1) pp. 89-97, 2006.

[6] Nakayama, F. S. and Bucks, D. A., Water-quality in drip/trickle irrigation a review. Irrigation Science, 12 (4), pp. 187-92, 1991.

[7] Yan, D., Bai, Z., Rowan, M., Gu, L., Shumei, R. and Yang, P., Biofilm structure and its influence on clogging in drip irrigation emitters distributing reclaimed wastewater. Journal of Environmental Sciences, 21(6), pp. 834-41, 2009.

[8] Capra, A. and Scicolone, B., Assessing dripper clogging and filtering performance using municipal wastewater. Irrigation and Drainage, 54 (S1), pp. S71-S79, 2005. 
[9] Duran-Ros, M., Puig-Bargués, J., Arbat, G., Barragán, J. and Cartagena, F.R.d., Performance and backwashing efficiency of disc and screen filters in microirrigation systems. Biosystems Engineering, 103(1), pp. 35-42, 2009.

[10] Nakayama, F. S., and Bucks, D. A. Trickle Irrigation for Crop Production: Design, Operation and Management. Amsterdam: Elsevier Science Publishers, 1986.

[11] Jensen, M. E., Design and Operation of Farm Irrigation Systems. ASAE Monograph. American Society of Agricultural Engineers, St. Joseph, Michigan, pp. 663-717, 1980.

[12] Adin, A. and Sacks, M., Dripper-clogging factors in wastewater irrigation. Journal of Irrigation and Drainage Engineering, 117(6), pp. 813-26, 1991.

[13] Keremane, G. B. and McKay, J., Successful wastewater reuse scheme and sustainable development: a case study in Adelaide. Water and Environment Journal, 21(2), pp. 83-91, 2007.

[14] Zhang, J., Zhao, W., Tang, Y. and Lu, B., Anti-clogging performance evaluation and parameterized design of emitters with labyrinth channels. Computers and Electronics in Agriculture, 74(1), pp. 59-65, 2010.

[15] Qingsong, W., Gang, L., Jie, L., Yusheng, S., Wenchu, D. and Shuhuai, H., Evaluations of emitter clogging in drip irrigation by two-phase flow simulations and laboratory experiments. Computers and Electronics in Agriculture, 63(2), pp. 294-303, 2008.

[16] Smith, C. A., Phiefer, C. B., Macnaughton, S. J., Peacock, A., Burkhalter, R. S., Kirkegaard, R. and White, D. C., Quantitative lipid biomarker detection of unculturable microbes and chlorine exposure in water distribution system biofilms. Water Research, 34(1), pp. 2683-88, 2000.

[17] Barbagallo, S., Cirelli, G. L. and Indelicato, S., Wastewater reuse in Italy. Water Science and Technology, 43(10), pp. 43-50, 2001.

[18] Duran-Ros, M., Puig-Bargués, J., Arbat, G., Barragán, J. and Cartagena, F.R.d., Effect of filter, emitter and location on clogging when using effluents. Agricultural Water Management, 96 (1), pp. 67-79, 2009.

[19] Townsend, B., Personal communication, 11 November 2011, Process Analyst, SA Water Corporation, Adelaide, Australia. Waterscope Report: Bolivar DAFF water quality sampling results after chlorine composite, 2011.

[20] Keller, J. and Bliesner, R. D., Sprinkle and Trickle Irrigation. Van Nostrand Reinhold, New York, pp. 440-452, 1990.

[21] ANZECC, Australian and New Zealand guidelines for fresh and marine water quality. Australian and New Zealand Environment and Conservation Council, Agriculture and Resource Management Council of Australia and New Zealand, Canberra, 2000.

[22] Ayers, R. and Westcot, D., Water quality for agriculture: FAO Irrigation and Drainage Paper 29. Rome, 1994.

[23] Bucks, D. A., Nakayama, F. S. and Gilbert, R. G., Trickle irrigation water quality and preventive maintenance. Agricultural Water Management, 2(2), pp. 149-62, 1979. 
[24] Jarwal, S., Bolanda, A. M., Stevensb, D. and Faggian, R., Using Recycled Water in Horticulture: A Growers Guide. Department of Primary Industries, Victorian Government, Melbourne, pp. 5-9, 2006.

[25] Radcliffe, J., An overview of water recycling in Australia-results of a recent ATSE study. Proc. of the Second National Conference of Water Recycling Australia, Melbourne, pp. 1-7, 2003.

[26] Hamilton, A. J., Boland, A.M., Stevens, D., Kelly, J., Radcliffe, J., Ziehrl, A., Dillon, P. and Paulin, B., Position of the Australian horticultural industry with respect to the use of reclaimed water. Agricultural Water Management, 71(3), pp. 181-209, 2005. 